\title{
THE EFFECT OF TRAINING METHOD AND MOTOR ABILITY TO POWER DOLLYO CHAGI KICK TAEKWONDO
}

\author{
Jonas Solissa ${ }^{1}$, James A.P. Tangkudung ${ }^{2}$ \\ ${ }^{1}$ Lecturer of Physical Education, Health, and Recreation Study Program \\ FKIP University of Pattimura Ambon, Indonesia \\ ${ }^{2}$ Universitas Negeri Jakarta, Indonesia

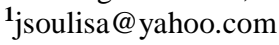

\begin{abstract}
The purpose of this research is to determine the effect of plyometrics training methods and weight training methods on the explosive power of Taekwondo dollyo chagi kicks. The study was conducted to the students of physical education and health FKIP Pattimura University of Ambon in 2012. The method of this research used field experiment with factorial design $2 \times 2$. From the results of ANOVA test, it was found: (1) There was explosive power difference between the Chagi Dollyo kick used plyometrics method exercises and weight training method, (2) There was interaction between the training methods and motor ability to the explosive power of Taekwondo dollyo chagi kick, (3) The athletes of high motor ability there were significant differences in the increasing of explosive power dollyo chagi kick between plyometrics methods exercises and weight training methods. (4) The athletes of low motor ability there were not significant differences in the increasing of explosive power dollyo chagi kick between with weight training method plyometrics training methods.
\end{abstract}

Keywords: efeck; training methods; power kick; motor ability.

Training and development in a branch of sport is a part of effort to improve sport achievement, yet, a careful planning is needed through an integrated, systematic, and sustainable system of training.

With the focus on Maluku area, the training achievement quality of Taekwondo sport which has been done so far is still left behind compared to other areas. It can be seen from the achievement development seen from four time PON activities which has declined significantly. In PON XV, Taekwandos achieved 1 gold medal, two silver medals, and two bronze medals. In PON XVI, Taekwandos achieved 5 bronze medals. In PON XVII, Taekwandos achieved 1 bronze medal. And, in PON XVIII, Taekwandos achieved 1 bronze medal.

Viewed from technical aspect, the declining achievement is due to the weakness in training process. The mentioned weakness is related to the process of physical condition training done by coaches unsistematically. It can be seen during competition. Taekwondoin (Taekwondo athlete) was not able to pass until final round.

The training of physical condition cannot be separated from a structural analysis of Taekwondo sport achievement. Competition demand and training need must be seen as a complex combination of a training process. In addition to the mastery of basic technique, Taekwondo development and training are adapted to the knowledge and principles of achievement sport, which generally emphasizes on maximal body 
ability. The abilities are strength, endurance, speed, power, flexibility, agility, reaction, fitness.

Power is a physical condition which has an important role in sport activity, both as a supporting aspect for certain movement and main aspect of an effort to achieve perfect movement technique. Power in Taekwondo is one of key components to win Taekwondo competition. Bompa (1994:76) defines power as the result of maximum power times maximum speed. Furthermore, Ginnis (2005:122) explains that power is the product of power resulted by fast working muscle with strong contraction to be more powerful compared to slow working muscle.

Current Taekwondo competition system applies electronic scoring system to provide fairness and avoid dirty games in Taekwondo that might be resulted by manual system. In reality, to get a score from a kick is not easy. A score will be given only for powerful kick. A powerless kick will not result in a score. Currently, it has been a challenge for coaches to find the appropriate training method in order to improve power in Taekwondo kick.

Kornikov in Bompa (1994:71) said that in sport physical ability cannot be separated from technical mastery because technical elements are hard to develop without physical ability support. Conversely, good physical ability will make the development of technique in the sport easier.

To optimize the physical condition of taekwondoin based on the above explanation, scientific solution is needed to find an appropriate training method to solve the problem.

The development of physical condition in order to improve power in Taekwondo kick can be done by using plyometric training method and weight exercise method. Barnes (2003:3) says that plyometric training is a form of natural explosive training in order to trigger body nerve system so that the performance is more effective. Donald Chu (1992:1) explains that plyometric training method is a training way which creates stronger muscle contraction with explosive movements as the main key of success of the whole track and field activities. This term is often used to relate repetitive jumping activities or stretch reflex exercise to produce an explosive reaction.

Plyometric exercise method has specific characteristics, namely, very strong muscle contraction and fast response of involved muscle weighting to improve strength and speed along with power so that weight training is one of training methods which is mostly used by sport coaches to develop and improve athlete's physical condition. In sport field, weight training is used to build general physical condition or specific physical condition.

Dreger (2006:78) states that weight training is a physical activity done systematically by using weight as a tool to improve athlete's physical condition. O'Shea (1976:25) explains that the purpose of this weight training for athletes is to develop muscle strength, muscle power, and muscle endurance.

Therefore, in order to improve power of Taekwondo kick, a taekwondoin must have good motor ability. According to Kirkendal (1980:213), motor ability is one's general quality to do movement skill easily. Wall and Murry (1994:20) defines that motor ability is one's performance capacity to do various movement tasks. Oxendine (1968:303) defines motor ability as a description of one of proficiencies to perform various basic skills and the whole physical activities. 
The main purpose of this research is to find the influence of plyometric training method and weight training method on kick power of dollyo chagi Taekwondo.

The relevant study for this study is one by Bismar (1994:151) which finds that there is a difference between plyometric training result and weight training result towards the study result of forehand drive in outdoor tennis. The result of this study concludes that the influence of training with plyometric method is higher significantly than weight training, with t count 2,40 and t tabel 1,68.

\section{METHOD}

The methodology used in this study is an experiment method with Treatment by Level 2 x 2 design. The reacheable population is 90 people, chosen with particular consideration (purposive sampling). Sample choice uses percentage technique 27\% for upper limit and $27 \%$ for lower limit which represents a group with low motor ability and the division of cell groups is randomly drawn. The sample number in this study is 40 people divided into four cells of 12 people in each cell.

The research instruments used to collect data are: (1) kick power instrument developed to measure dollyo chagi kick power, and (2) Motor ability instrument measured by Barrow's motor ability test.

Data collected in this study are processed and analyzed by using two way variant analysis (ANOVA) with significant rate $\alpha 0,05$ and then continued by Tuckey test. Liliefors test is used to test data normality and Barlet test is used to test data homogeneity.

\section{RESULTS}

The detail processes of discussing the study result from every variable based on the research finding and hypothesis testing, are as follow:

\section{There is difference of Dollyo Chagi kick power between Plyometric Training Method and Weight Training Method}

Based on variant analysis result (ANOVA) on significant rate $\alpha=0,05$, it can be counted that $\mathrm{F}_{\text {count }}=10,667$ dan $\mathrm{F}_{\text {table }}=4,043$ atau $\mathrm{F}_{\text {count }}>\mathrm{F}_{\text {table }}$ with significance 0,002 . It can be concluded that in total there is significant difference between the effect of plyometric training method and weight training method on dollyo chagi Taekwondo kick power. In another word, kick power uses plyometric training method $\bar{X}=43.03$ more than weight training method $\bar{X}=37.35$. It means that the research hypothesis which states that in total that there is a difference between kick power resulted from plyometric training method and weight training method is proven. From ANOVA result testing, the significant difference is found between plyometric training method and weight training method towards dollyo chagi Taekwondo kick power. 


\section{There is an interaction between Training Method and Motor Ability towards The Improvement of Kick Power of Dollyo Chagi Taekwondo.}

Variant analysis result between interaction between training method and motor method towards kick power shows value $F_{0}$ interaction $\left(F_{A B}\right)=F_{\text {-count }}=32,016>F_{\text {table }}$ $=4,043$ for $\alpha=0,05$ (significance 0,000 ). It means $F_{\text {count }}>F_{\text {table, }}$, so that Ho is refused. The conclusion is that there is an interaction between training method and motor ability towards kick power of dollyo chagi Taekwondo.

By testing the interaction, the further testing is needed. The further testing is aimed to find: a) Difference between plyometric training method and weight training method towards kick power of dollyo chagi for group with high motor ability; b) Different influence between pliomerik training method and weight training method towards kick power of dollyo chagi for group with low motor ability. The summary of further testing can be seen in the following table 1.

Table 1. Summary of Tuckey Testing Calculation Result

\begin{tabular}{ccccc}
\hline NO & Kelompok & Qhitung & Qtabel $_{(\boldsymbol{\alpha}=\mathbf{0 , 0 5})}$ & Keterangan \\
\hline 1 & $\mathrm{~A}_{1}$ dan $\mathrm{A}_{2}$ & 2,862 & 2,069 & Signifikan \\
2 & $\mathrm{~A}_{1} \mathrm{~B}_{1}$ dan $\mathrm{A}_{2} \mathrm{~B}_{1}$ & 4,256 & 2,201 & Signifikan \\
3 & $\mathrm{~A}_{2} \mathrm{~B}_{2}$ dan $\mathrm{A}_{1} \mathrm{~B}_{2}$ & 0,208 & 2,201 & Tidak Signifikan \\
\hline
\end{tabular}

3. There is different effect of Plyometric Training Method and Weight Training Method on Kick Power of Dollyo Chagi for group with high motor ability

Plyometric training method gives influence on kick power of dollyo chagi for group with high motor ability. It is proven based further test result in variant analysis (ANOVA) by using Tuckey Testing. Group with high motor ability with plyometric training method $\left(\mathrm{A}_{1} \mathrm{~B}_{1}\right)$ is compared to group with high motor ability with weight training method $\left(\mathrm{A}_{2} \mathrm{~B}_{1}\right)$ so that it is found $\mathrm{Q}_{\text {count }}=4,256$ and $\mathrm{Q}_{\text {table }}=2,201$. Therefore, $\mathrm{Q}_{\text {count }}$ is bigger than $\mathrm{Q}_{\text {table, }}$ so that $\mathrm{H}_{\mathrm{o}}$ is refused. It can be interpreted that there is the increase of kick power of dollyo chagi in real between plyometric training method and weight training method for group with high motor ability.

In another word, taekwondoin with high motor ability using plyometric training method is $\bar{X}=54.04$ bigger than it using weight training method which is $\bar{X}=$ 38.52 in kick power of dollyo chagi Taekwondo. As a result, the research hypothesis is proven that high motor ability with plyometric training method is better than with weight training method in improving kick power of dollyo chagi Taekwondo.

4. There is a Significant Difference of the Effect between Plyometric Training Method and Weight Training Method on the Improvement of Kick Power of Dollyo Chagi for Group with Low Motor Ability

Plyometric training method gives the influence on improvement of kick power for group with low motor ability. It is not proven based on the result of further testing in variant analysis (ANOVA) using Tuckey testing. Group with high motor ability using plyometric training method $\left(\mathrm{A}_{1} \mathrm{~B}_{1}\right)$ is compared to group with high motor ability using weight training method $\left(A_{2} B_{1}\right)$, so that it is found that $Q_{\text {count }}=4,256$ and 
$\mathrm{Q}_{\text {table }}=2$ 2,201. It means that $\mathrm{Q}_{\text {count }}$ is bigger than $\mathrm{Q}_{\text {table, }}$ so that $\mathrm{H}_{\mathrm{o}}$ is refused. It can be interpreted that there is a difference of kick power of dollyo chagi in reality between plyometric training method and weight training method for group with high motor ability.

In another word, taekwondoin with high motor ability using plyometric training method is $\bar{X}=54.04$ bigger than it using weight training method which is $\bar{X}=$ 38.52 in kick power of dollyo chagi Taekwondo. As a result, the research hypothesis is proven that high motor ability with plyometric training method is better than with weight training method in improving kick power of dollyo chagi Taekwondo.

\section{DISCUSSION}

Based on the hypothesis testing result statistically as explained above, the discussion of research result consists of four main points, namely:

1. Research hypothesis that suggests that taekwondoin trained using plyometric training method $\left(A_{1}\right)$ will give higher kick power of dollyo chagi Taekwondo than taekwondoin trained using weight training method $\left(\mathrm{A}_{2}\right)$ is accepted.

Effectiveness of pliometrik training method towards the improvement of kick power of dollyo chagi Taekwondo means that theoretically plyometric training method is better than weight training method because plyometric method is a form of training with specific charcteristic, namely very strong muscle contraction and a fast response of weighting on involved muscles to improve strength and speed along with power.

2. Hipothesis truth of second study shows that there is an interaction between training method and motor ability towards kick power of dollyo chagi Taekwondo, is accepted.

Hypothesis testing done proves that there is an interaction between training method and motor ability towards kick power of dollyo chagi Taekwondo. Taekwondoin group with high motor ability is trained using plyometric training method has higher kick power than group with high motor ability using weight training method.

Conversely, student group with low motor ability is trained using plyometric training method has lower kick power compared to student group with low motor ability trained using weight training method.

3. Hypothesis truth of third study that shows that taekwondoin group with high motor ability trained using plyometric training method $\left(A_{1} B_{1}\right)$ has higher kick power of dollyo chagi Taekwondo dari than taekwondoin group with higher motor ability trained using weight training method $\left(A_{2} B_{1}\right)$ is accepted.

Motor ability is general capacity in performing technical skills (special motor skill) in a branch of sport. One with high motor ability has definitely benefit in doing fast and perfect movement in training process.

Plyometric training method is a form of training which has specific characteristic, namely very strong contraction and a fast response to weighting of involved muscle to increase power. 


\section{Hypothesis truth of fourth study states that taekwondoin with lower motor ability trained using plyometric training method $\left(A_{1} B_{2}\right)$ has lower kick power of dollyo chagi than taekwondoin with lower motor abilitty trained using weight training method $\left(A_{2} B_{2}\right)$ is not accepted.}

Low motor ability shows that the level of readiness in learning and getting kick power is also low. It is proven in the training process of plyometric training for group with low motor ability, there is an obstacle to practice the movements with high level of difficulty, accurately and explosively based on the requirement of plyometric training method.

For weight training method, group with low motor ability does not find significant obstacle because weight training with lifting or facing out weight regularly and in which the weight is increased step by step progressively will trigger leg muscle to have fast contraction so that it produces big strenght and speed along with high power.

If it is seen from the difference mean, weight training method is better than plyometric training method but the difference is empirically not significant. Nevertheless, the recommendation for those with low motor ability is that they may choose plyometric training and weight if they want to improve their kick power.

Based on the result, it can be concluded that: (1) in total, the result of kick power of dollyo chagi Taekwondo through the implementation of plyometric training method is better than it of weight training method, (2) there is an interaction between training method and motor ability towards kick power of dolyo chagi Taekwondo, (3) for taekwondoin with high motor ability, plyometric training method is better than weight training method in terms of influence on kick power of dollyo chagi Taekwondo, (4) for taekwondoin with low motor ability, there is no significant difference between plyometric training method and weight training method in terms of the influence on kick power of dollyo chagi Taekwondo.

\section{CONCLUSION}

Based on the above research result and discusssion, it can be concluded that: (1) in total, the result of kick power of dollyo chagi Taekwondo through the implementation of plyometric training method is better than it of weight training method, (2) there is an interaction between training method and motor ability towards kick power of dolyo chagi Taekwondo, (3) for taekwondoin with high motor ability, pliometric training method is better than weight training method in terms of influence on kick power of dollyo chagi Taekwondo, (4) for taekwondoin with low motor ability, there is no significant difference between plyometric training method and weight training method in terms of the influence on kick power of dollyo chagi Taekwondo.

Implication of these findings proves that: (1) Motor ability needs to be considered in developing Taekwondo kick power, training to improve kick power by at first improving motor ability, (2) It is proven that plyometric training method is more effective to improve kick power of dollyo chagi Taekwondo. 


\section{REFERENCES}

Bompa, Tuodor O. (1994). Theory and Methodology of training dubugue: IOWA Kendal/hunt, pub Camp.

Barnes, Michel. Infroduction to Plyometrics. (2003). Journat SCA": Performance Training, Vol.2, Number 2 (www-nsca = lift.orq/perform).

Bismar, Rum. (2004). Pengaruh Latihan Pliometrik dan Latihan Beban Terhadap Hasil Belajar Forehand Drive Tenis Lapangan, (Jakarta: Disertasi Pps UNJ Jakarta.

Chu, Donald. (1992). Jumping Into Plyometrics, California : Leisure Press.lllinois.

Ginnis, Mc. Peter Merton. (2005). Biomechanics of Spot and Exercise Seven Edition United States of America: Human Kineticcs.

Kirkendall, Don R. (1997). Measurement and Evaluation for Physical Education, diterjemahkan oleh M E. Winarno, dkk. Jakarta: ASWIN.

Laporan Kerja KONI Provinsi Maluku. (2012).

O'Shea J.P. (1976). Scientefic Principles and Methodology Strength Fitness. California: Addision Westley Publishing Company.

Oxidine, Josep B. (1968). Psycology of Motor Leaming New York: AppletonCentury-Crofts.

Suryadi. (2002). Yoyok Taekwondo Poomse Taegeuk. Jakarta: PT Gramedia.

Sudjana. (2002). Disain dan Analisis Eksperimen, Bandung: Tarsito.

Undang-undang RI. (2005). Tentang Sistem Keolahragaan Nasional, Jakarta: Menegpora.

Verducci, Frank M. (1980). Measurement Concept in Physical Education. St.Louis: Mosby Company.

Wall Jenifer dan Murray Nancy. (1994). Children \& Movement, Physical Education in The Elementary School, Lowa: ECB Brown \& Benchmark. 